\title{
Seasonal Influence in Traffic-Related Air Pollutants Concentrations in Urban Parks from Porto Alegre, Brazil
}

\author{
Bruna Marmett ${ }^{(}$, Roseana Böek Carvalho* ${ }^{\circledR}$, Fernanda Ramos Rhoden, Cláudia Ramos Rhoden ${ }^{(1)}$ \\ Laboratory of Atmospheric Pollution, Graduate Program in Health Science, Federal University of Health Sciences of Porto Alegre \\ (UFCSPA), Porto Alegre, Brazil \\ Email: *roseanaboek@gmail.com
}

How to cite this paper: Marmett, B., Carvalho, R.B., Rhoden, F.R. and Rhoden, C.R. (2019) Seasonal Influence in Traffic-Related Air Pollutants Concentrations in Urban Parks from Porto Alegre, Brazil. Open Journal of Air Pollution, 8, 96-107.

https://doi.org/10.4236/ojap.2019.84005

Received: July 25, 2019

Accepted: November 5, 2019

Published: November 8, 2019

Copyright $\odot 2019$ by author(s) and Scientific Research Publishing Inc. This work is licensed under the Creative Commons Attribution International License (CC BY 4.0).

http://creativecommons.org/licenses/by/4.0/

\begin{abstract}
Traffic-related air pollution is an alarming source of pollutants exposure and consequently to the development of several adverse health effects. Otherwise, green spaces are reported to improve health status. Although, in an urban scenario most of these areas are located near air pollutants sources, as vehicle fleet. Thus, the aim of the present study was to determine, during one year, the levels of nitrogen dioxide $\left(\mathrm{NO}_{2}\right)$ and ozone $\left(\mathrm{O}_{3}\right)$ in the main parks from Porto Alegre-Brazil. This study focused on three urban parks: Germânia, Moinhos de Vento and Marinha do Brasil Park. Nitrogen dioxide and ozone measurements were accessed by passive monitoring in four campaigns including all seasons and performed at distances of $0 \mathrm{~m}, 15 \mathrm{~m}, 30 \mathrm{~m}, 45 \mathrm{~m}, 60 \mathrm{~m}$ and $75 \mathrm{~m}$ from the main road at each park. $\mathrm{NO}_{2}$ and $\mathrm{O}_{3}$ concentration among the parks was not different $(p>0.05)$, as well as the mean concentration of $\mathrm{NO}_{2}$ and $\mathrm{O}_{3}$ of all parks in the six sites did not differ $(p>0.05)$. However, season 1 and 3 showed increased $\mathrm{NO}_{2}$ and $\mathrm{O}_{3}$ concentration. Temperature were decreased in season 1 and $3(p<0.05)$, while humidity, pressure and insolation showed no difference among seasons $(p>0.05)$. Traffic flow was higher in Moinhos de Vento Park and Marinha do Brasil Park compared to Germânia Park $(p<0.05)$. Overall, the seasonal variation could directly interfere in $\mathrm{NO}_{2}$ and $\mathrm{O}_{3}$ concentration in urban parks from Porto Alegre.
\end{abstract}

\section{Keywords}

Air Pollution, Environmental Monitoring, Urban Parks, Seasonal Variation

\section{Introduction}

Air pollution has become a major risk factor threatening human health. In 
modern metropolises, the requirement of a huge amount of environmental resources occurs mainly due to the accelerated expansion of the economy and population growing [1] [2]. The exposure to a polluted atmosphere may result in damage to our environment and potential health risk to humans. Reports demonstrated that every year outdoor air pollution is responsible for 4.2 million deaths around the world, while indoor air pollution for 3.8 million deaths [3]. Exposure to air pollutants as nitrogen dioxide $\left(\mathrm{NO}_{2}\right)$ and ozone $\left(\mathrm{O}_{3}\right)$ has been correlated with increase in mortality and hospital admissions caused by respiratory and cardiovascular diseases. These outcomes have been found both in short and long-term studies [4] [5] [6] [7].

Our society still relies heavily on fossil fuels for various purposes, such as transportation, due to this, traffic-related air pollution is an alarming source of human exposure to air pollutants [2] [8]. Many health studies have connected adverse health effects with spending significant amounts of time near high-traffic roads with elevated air pollution levels [9] [10] [11] [12]. Otherwise, green spaces are reported to improve health status once people use public areas to perform physical activity and have a leisure time, which serves as a key strategy to maintain and improve population health [13]. Although, in an urban scenario, most of these areas are located near air pollutants sources, as vehicle fleet [14]. Some researchers have alert that health risks from exposure to air contaminants may increase during exercise because ambient air pollutants affect health and exercise may amplify the respiratory uptake and deposition of air pollutants in the lungs [15]-[20].

Trees and other vegetation reduce air pollution levels through the interception of airborne particles or through the uptake of gaseous air pollution through leaf stomata on the plant surface [21] [22] [23] [24]. On the other hand, Nowak and colleagues (2010) showed that removed pollution particles can be re-suspended to the atmosphere during turbulent winds, negatively impacting local air. Besides that, high vegetation can reduce mixing and turbulence resulting in increased pollutants concentration levels [25]. This can be explained by the fact that trees and other types of vegetation reduce the ventilation that is responsible for diluting the traffic emitted pollutants. Several studies demonstrated that green spaces located in urban street canyons can obstruct the wind flow thereby reducing the ventilation leading to higher pollutant concentrations [26] [27].

In view of the indisputable health benefits of exercising and having leisure times together with the little amount of knowledge about the levels of air pollution at public urban parks it is important to know the concentration of pollutants gases and understand the factors that affects it. So, the aim of the present study was to determine, during one year, the levels of $\mathrm{NO}_{2}$ and $\mathrm{O}_{3}$ in the main parks from Porto Alegre-Brazil.

\section{Methods}

\subsection{Study Area}

The study was conducted in the city of Porto Alegre $\left(30^{\circ} 01^{\prime} 59^{\prime \prime} \mathrm{S}, 51^{\circ} 13^{\prime} 47^{\prime \prime} \mathrm{W}\right)$, 
which is the principal city from the state of Rio Grande do Sul, located in the Southern Brazil. This city has approximately 1.409 million inhabitants (2.83 people per $\mathrm{km}^{2}$ ) and the climate is considered humid-subtropical, with aboveaverage precipitation throughout the year.

This study focused on three representative urban parks that were chosen for field experiments: Germânia Park, situated at Túlio de Rose avenue $\left(30.0256^{\circ} \mathrm{S}\right.$, $51.1588^{\circ} \mathrm{W}$ ), comprising a green area of 15.11 hectares; Moinhos de Vento Park, situated at Goethe avenue $\left(30.0271^{\circ} \mathrm{S}, 51.2007^{\circ} \mathrm{W}\right)$, comprising a green area of 11.5 hectares and Marinha do Brasil Park, situated at Borges de Medeiros avenue $\left(30.0493^{\circ} \mathrm{S}, 51.2302^{\circ} \mathrm{W}\right)$, comprising a green area of 11 hectares (Figure 1). To avoid differences due to geographical distribution of air pollutants, $\mathrm{NO}_{2}$ and $\mathrm{O}_{3}$ sampling was performed at distances of $0 \mathrm{~m}, 15 \mathrm{~m}, 30 \mathrm{~m}, 45 \mathrm{~m}, 60 \mathrm{~m}$ and $75 \mathrm{~m}$ from the main road at each park (sites 1-6). The filters were installed in the corner of the parks, where was the intersection of the highways and then installed from the corner gradually to the center in a straight line within $15 \mathrm{~m}$ of distance from each other.

\subsection{Air Pollutants and Meteorological Parameters}

The four sampling campaigns (September/2017 = season 1; January/2018 = season 2; June $/ 2018$ = season 3; September $/ 2018$ = season 4) were chosen to examine pollutant patterns over more than one season, to ensure that our findings were robust over time. In each campaign vehicular traffic was recorded and blind analyses of vehicular flow was performed by two observers. Climatic variables (air temperature, relative humidity, pressure, wind direction and insolation) were obtained from INMET (National Institute of Meteorology) recorded at José Luiz Carneiro Cruz public square (Porto Alegre, Brazil).

In this study, cellulose filters (37 mm, Energética, Rio de Janeiro, Brazil) were used as a diffusive surface into a sampler which was placed in trees at a height of 2 meters, as illustrated in Figure 2. $\mathrm{NO}_{2}$ measurements followed Lodge $\mathrm{Jr}$ (1988)

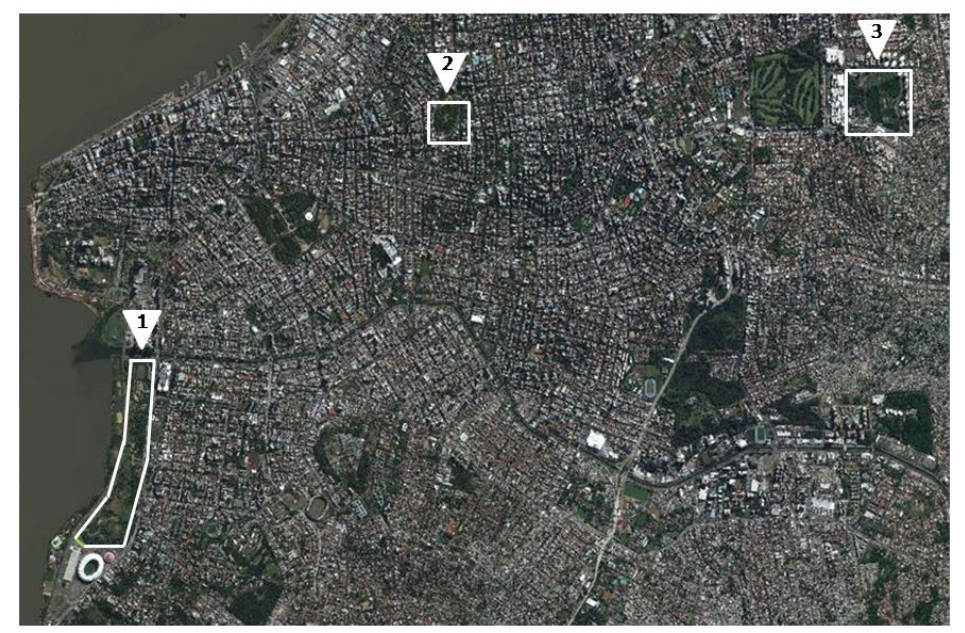

Figure 1. Spatial distribution of investigated parks. 1) Marinha do Brasil Park; 2) Moinhos de Vento Park; and 3) Germânia Park. 


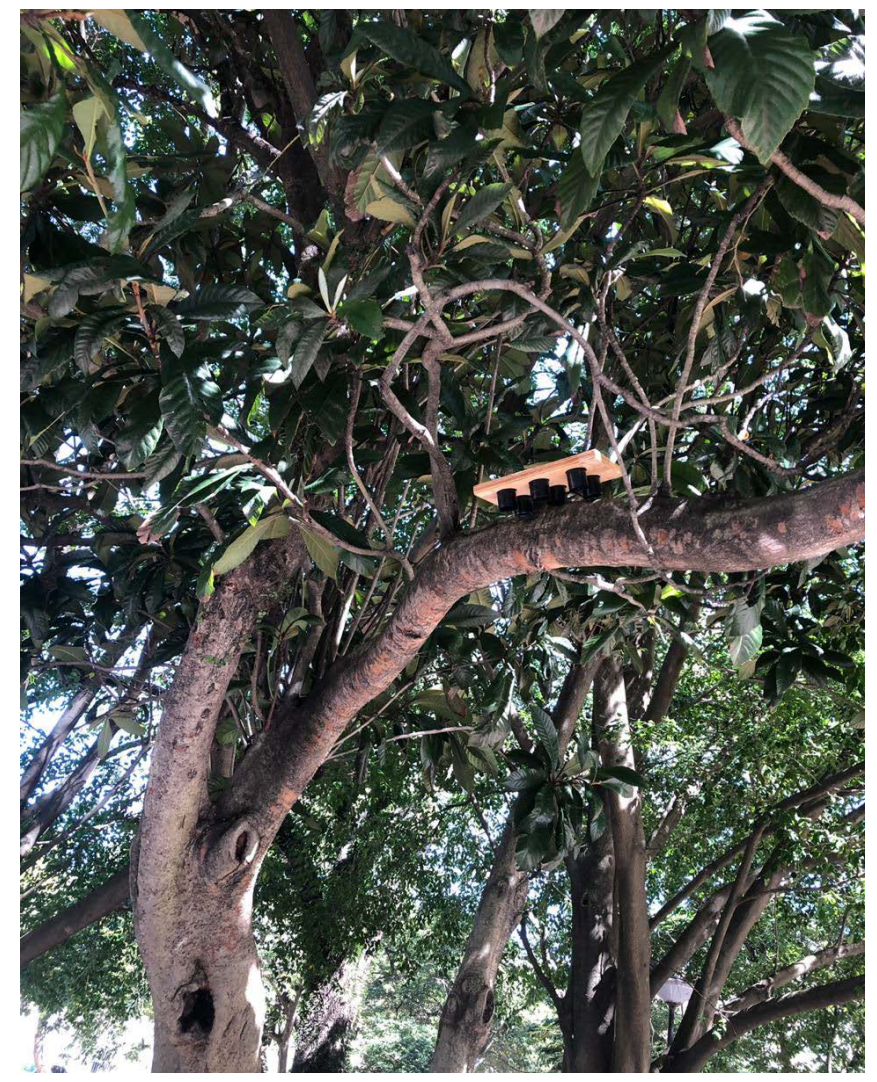

Figure 2. Filters of $\mathrm{NO}_{2}$ and $\mathrm{O}_{3}$ installed in park trees for monitoring sampling.

protocol [28]. Cellulose filters were impregnated with triethanolamine $(200 \mu \mathrm{L})$, as a liquid absorber solution, and then dried at $37^{\circ} \mathrm{C}$ for $24 \mathrm{~h}$. After this period, filters were placed in open plastic tubes and placed at monitoring areas for 7 days. Blank filters were acquired using filters in the same conditions as the exposed but without atmosphere contact, inside a closed ziplock bag. The solution obtained was analyzed spectrophotometrically at $550 \mathrm{~nm}$ (Perkin-Elmer Lambda 35, São Paulo, Brazil).

$\mathrm{O}_{3}$ measurements followed Scheeren and Adema (1996) protocol [29]. Cellulose filters were impregnated with indigo carmine as a liquid absorber solution in a dark ambient to prevent the degradation light effect. After impregnating the filters with $200 \mu \mathrm{L}$ of absorber solution, they were left to dry for $4 \mathrm{~min}$ in room temperature before a second impregnating procedure $(200 \mu \mathrm{L})$. After this period, filters were placed in dark open plastic tubes and placed at monitoring areas for $24 \mathrm{~h}$. Blank filters were acquired using filters in the same conditions as the exposed but with no contact with direct sunlight and atmosphere (inside an aluminum foil ziplock bag) contact. The solution obtained was analyzed spectrophotometrically at $610 \mathrm{~nm}$ (Perkin-Elmer Lambda 35, São Paulo, Brazil).

\subsection{Statistical Analysis}

Statistical analysis was carried out using SigmaPlot version 12.0 for Windows (Systat Software, Inc.) and GraphPad Prism version 6.0 for Windows (Prism 6; 
GraphPad Software, Inc.). Study variables were tested for normality using Shapiro-Wilk or Kolmogorov-Smirnov test. To analyze parks and sites variables we used one-way ANOVA, followed by Tukey's post hoc test. The interaction between parks and seasons were obtained by two-way ANOVA, followed by $\mathrm{Tu}$ key's post hoc test. Values were reported as mean \pm standard deviation. A $p<$ 0.05 was considered statistically significant.

\section{Results}

In the present study, $\mathrm{NO}_{2}$ concentration among the parks was not different ( $p=$ 0.447 ) (Figure 3(a)). The $\mathrm{NO}_{2}$ concentration average of all parks in the six sites did not differ among them $(p=0.993)$ (Figure $3(b))$. In season $1, \mathrm{NO}_{2}$ concentration were increased when compared to season $2(p=0.007)$. Also, it was observed an increase of $\mathrm{NO}_{2}$ concentration in season 3 when compared to seasons 1 ( $p=$ $0.048), 2(p<0.001)$, and $4(p<0.001)$ (Figure $3(c))$. While, when the interaction of seasons with the parks was compared, it was observed an increase of $\mathrm{NO}_{2}$ concentration in season 1 compared to season $2(p=0.005)$ and in season 3 compared to seasons $1(p=0.0449), 2(p<0.001)$, and $4(p<0.001)$ in all parks (Figure $3(\mathrm{~d}))$.

(a)

(b)

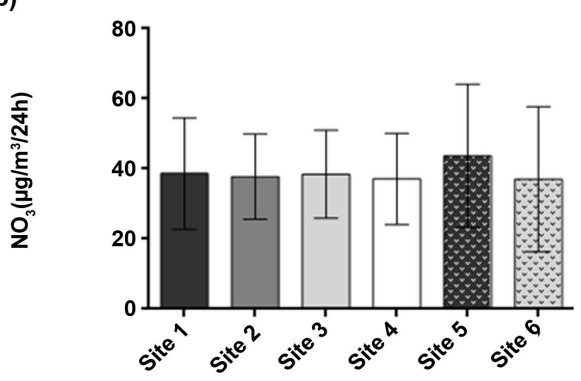

(c)

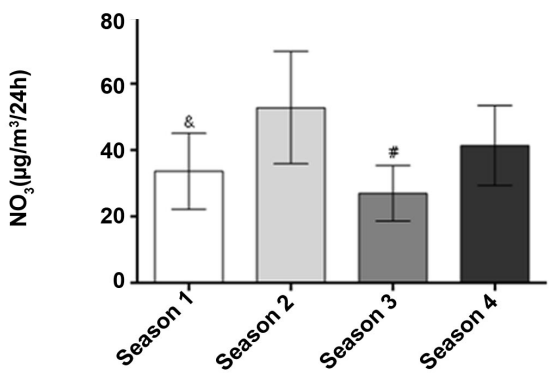

(d)

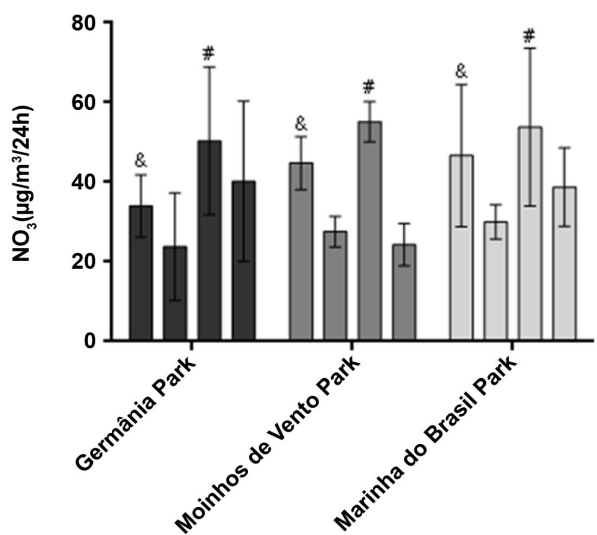

Figure 3. $\mathrm{NO}_{2}$ concentrations in monitoring parks; (a) $\mathrm{NO}_{2}$ concentration in all parks during the year; (b) $\mathrm{NO}_{2}$ concentration in the six sites of the parks; (c) $\mathrm{NO}_{2}$ concentration in the four seasons; (d) $\mathrm{NO}_{2}$ concentration of four seasons in parks. Values presented as mean \pm SD. Statistical analysis: one-way ANOVA followed by Tuckey's post hoc test for Figure 3(a) and Figure 3(b); two-way repeated measures ANOVA followed by Tuckey's post hoc test for Figure 3(c). Symbols represent comparison among groups based on the post hoc analysis: $\&-p<0.05$ vs. 2 ; \#-p $<0.05$ vs. 1,2 and 4. GraphPad Prism (Prism 6; GraphPad Software, Inc.) were used to graphs elaboration. 
Regarding $\mathrm{O}_{3}$ concentrations, a difference among the parks was not observed $(p=0.670)$ (Figure 4(a)). Also, the $\mathrm{O}_{3}$ concentrations among the six sites of the parks were not different $(p=0.898)$ (Figure $4(\mathrm{~b})) . \mathrm{O}_{3}$ concentrations in seasons demonstrated an increase in season 1 and 3 compared to season $2(p<0.001)$ and $4(p<0.001)$, and augment in season 2 when compared to season $4(p=$ 0.025) (Figure $4(c)$ ). In addition, the $\mathrm{O}_{3}$ concentration in Germânia Park was increased in seasons 1 and 3 when compared to seasons $2(p<0.001)$ and $4(p<$ 0.001). In Moinhos de Vento Park, the $\mathrm{O}_{3}$ concentration was increased in season 1,2 and 3 compared to season $4(p<0.001)$. In Marinha do Brasil Park, the $\mathrm{O}_{3}$ concentration was increased in season 1 when compared to season $2(p=0.030)$ and $4(p<0.001)$, and season 3 compared to season $1(p<0.001), 2(p<0.001)$ and $4(p<0.001)$. Marinha do Brasil Park showed increased $\mathrm{O}_{3}$ concentration in season 3 when compared to all seasons in Germânia $(p<0.001)$ and Moinhos de Vento $(p<0.001)$ parks (Figure $4(\mathrm{~d})$ ).

The meteorological measures of the seasons showed that season 1 and 3 had decrease temperatures compared to seasons 2 and $4(p<0.05)$. Humidity, pressure and insolation showed no difference among seasons (Figure 5). When assessed

(a)

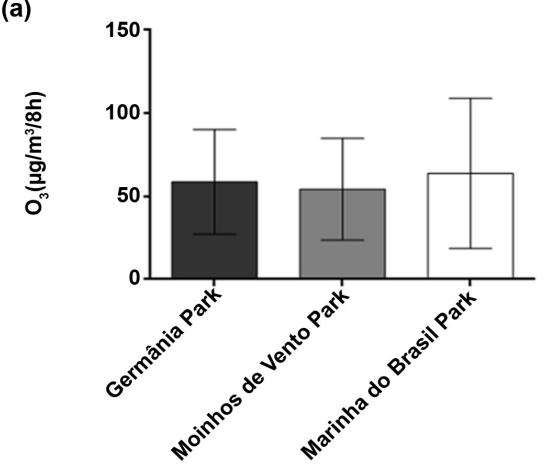

(b)

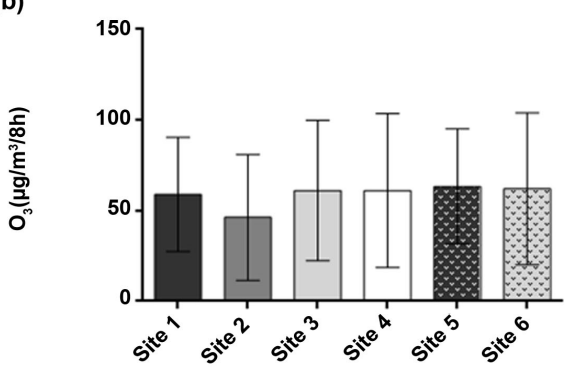

(c)

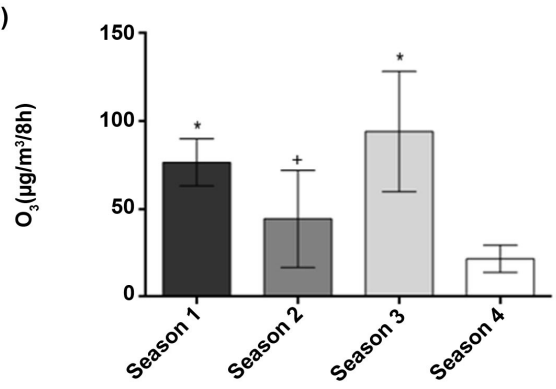

(d)

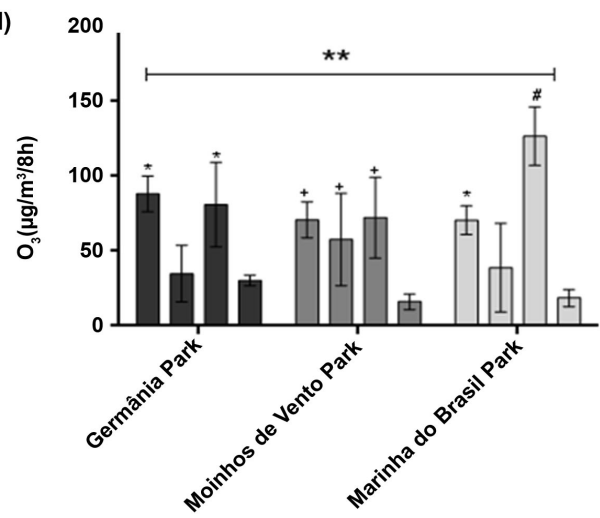

Figure 4. $\mathrm{O}_{3}$ concentrations in monitoring parks; (a) $\mathrm{O}_{3}$ concentration in all parks during the year; (b) $\mathrm{O}_{3}$ concentration in the six sites of the parks; (c) $\mathrm{O}_{3}$ concentration in the four seasons; (d) $\mathrm{O}_{3}$ concentration of four seasons in parks. Values presented as mean \pm SD. Statistical analysis: one-way ANOVA followed by Tuckey's post hoc test for Figure 4(a) and Figure 4(b); two-way repeated measures ANOVA followed by Tuckey's post hoc test for Figure 4(c). Symbols represent comparison among groups based on the post hoc analysis: ${ }^{\star}-p<0.05$ vs. 2 and $4 ;+-p<0.05$ vs. 4 ; \#-p $<0.05$ vs. 1,2 and 4 ; ${ }^{\star \star}-p<0.05$, season 3 of Marinha do Brasil Park vs. all seasons of parks. GraphPad Prism (Prism 6; GraphPad Software, Inc.) were used to graphs elaboration. 
(a)

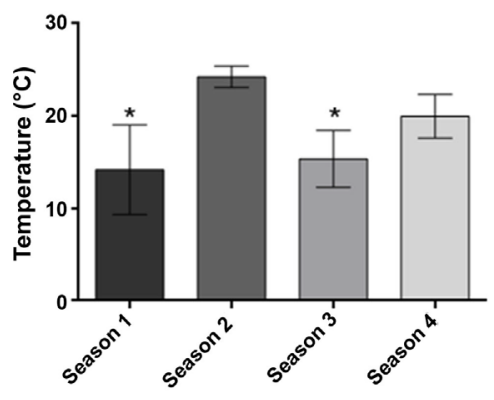

(b)

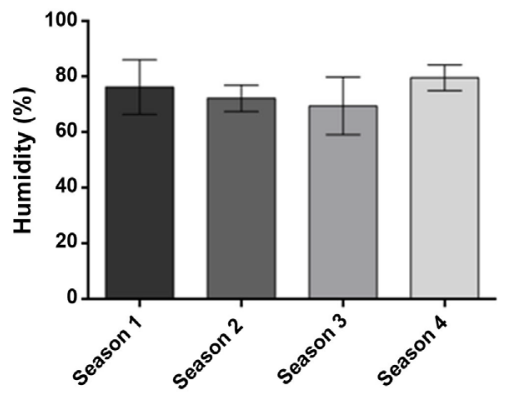

(c)

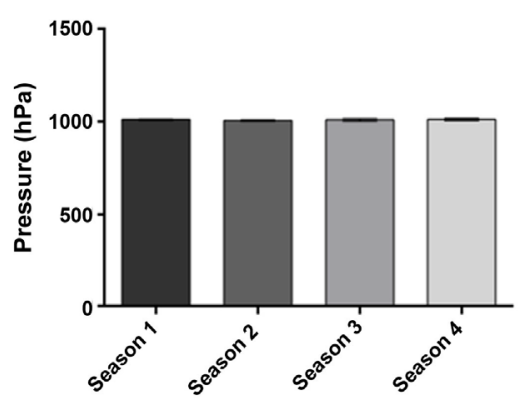

(d)

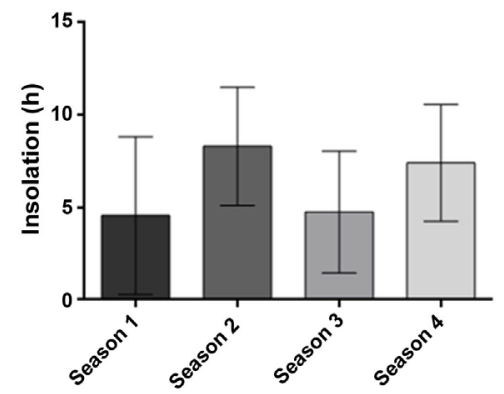

Figure 5. Meteorological measures of monitoring seasons. (a) Temperature; (b) Humidity; (c) Pressure; (d) Insolation. Values presented as mean \pm SD. Statistical analysis: one-way ANOVA followed by Tuckey's post hoc test. Symbols represent comparison among groups based on the post hoc analysis: ${ }^{\star}-p<0.05$ vs. 2 and 4. GraphPad Prism (Prism 6; GraphPad Software, Inc.) were used to graphs elaboration.

the traffic flow in streets surrounding the parks, Moinhos de Vento Park showed a higher traffic flow compared to Germânia Park and Marinha Park $(p<0.05)$ being the number of cars/minute of 108 and 36, respectively. Also, Marinha Park demonstrated increased traffic flow compared to Germânia Park $(p<0.05)$, with 69 cars/minute.

\section{Discussion}

The results of this study showed a seasonal variation of pollutants concentrations among urban parks, demonstrating that mainly season 1 and 3 had higher concentrations of $\mathrm{NO}_{2}$ and $\mathrm{O}_{3}$. The unique meteorological measure that may potentially interfere in this variation is temperature. So, in the seasons with lower temperature, an increase on traffic-related air pollution concentration was detected. Furthermore, there was no difference among parks concentration of $\mathrm{NO}_{2}$ and $\mathrm{O}_{3}$, neither a gradient of the pollution dispersion was observed in this study.

The absence of difference in $\mathrm{NO}_{2}$ and $\mathrm{O}_{3}$ concentration among parks during the year indicates that studied parks demonstrated similar levels of air pollutants. However, the seasonal variation observed in our study influence the concentration of pollutants concentrations, given that an increase in $\mathrm{NO}_{2}$ and $\mathrm{O}_{3}$ concen- 
trations was observed in the coldest seasons (1 and 3). In contribution to our result, cold seasons are associated with high pollution episodes, being the highest levels of pollutants occurring in winter [30] [31] [32] [33]. During low temperature and winter days, thermal inversion is commonly observed, and, in this period, the concentration of pollutants tends to be higher, leading to a poor air quality environment [34]. Also, parks could intensify low temperature and contribute to pollution concentration due to the shading and cooling effect caused by trees that act as barrier of pollutants [35] [36].

Season 3 of Marinha do Brasil Park had increased levels of $\mathrm{O}_{3}$ when compared to all seasons in other parks. Despite vegetation of urban parks be recognized to mitigate the pollutants concentration in green areas, some characteristics must be taken into account, as structural aspects: vegetation structure, composition and management, considering the components in terms of trees, shrubs, herbaceous vegetation and lawns [21] [36]. So, the difference observed in our study may be a result from structural characteristics of Marinha do Brasil Park.

The formation of a pollution gradient depends on distance, barriers and type of pollutant, and a decay of half of the maximum concentration pollutant could occurred at a distance around $150 \mathrm{~m}$ from the source [37] [38] [39]. In our study, we evaluated the concentration of $\mathrm{NO}_{2}$ and $\mathrm{O}_{3}$ in a gradient way with sites $15 \mathrm{~m}$ from each other, starting in the board of the park through the center, summering $75 \mathrm{~m}$ and no difference was observed among the sites. In a study of Chang and colleagues (2015), a framework to inform exposure estimates for traffic-related air pollutants with a high spatial resolution was developed and it was demonstrating that concentrations of traffic-related air pollutants drop by over $40 \%$ within $200 \mathrm{~m}$ away from the roadway [40]. So, the distance analyzed in our study was not enough to cause a decrease in $\mathrm{NO}_{2}$ and $\mathrm{O}_{3}$ concentrations. Overall, urban parks from Porto Alegre are not sufficiently extensive to mitigate the pollution concentration by dispersion.

Regarding the traffic flow in streets surrounding the parks, although Moinhos de Vento Park had increased traffic compared to other parks and Germânia the lower traffic, these results did not interfere in pollution concentration detected, once it was not observed difference among parks when all seasons were included. However, when each season was analyzed, $\mathrm{O}_{3}$ concentrations in Moinhos de Ventos Park was higher in season 1, 2 and 3 compared to 4, while in other parks only season 1 and 3 was increased. So, this result could derivates of the high traffic flow in streets close to Moinhos de Vento Park, once road traffic is the main air pollutant emitter in urban areas [37] [41].

Our study had a limitation that must be considered. We did not measure additional pollutants released from vehicular emissions, such as $\mathrm{MP} 2.5$ and $\mathrm{SO}_{2}$. The levels of these pollutants associated with $\mathrm{NO}_{2}$ and $\mathrm{O}_{3}$ concentration could provide a more complex panorama to our study and a better understanding of our results. 


\section{Conclusion}

Thus far, the seasonal variation could directly interfere in $\mathrm{NO}_{2}$ and $\mathrm{O}_{3}$ concentration in urban parks from Porto Alegre. It indicates that cold seasons contribute to the deterioration of air quality. The sites of the parks seem not to interfere in the local air quality, since a gradient of pollutants concentration was not observed.

\section{Acknowledgements}

We are thankful to Federal University of Health Sciences of Porto Alegre (UFCSPA).

\section{Authors' Contributions}

Bruna Marmett and Roseana Böek Carvalho are both first authors of this study and had equal substantial contributions to conception, design, acquisition, analysis and interpretation of data. All authors have involvement in drafting the manuscript and revising it critically for important intellectual content and have approved the final version of the manuscript to be published.

\section{Funding}

This study has received support funding from Fundação de Amparo à Pesquisa do Estado do Rio Grande do Sul (FAPERGS).

\section{Conflicts of Interest}

The authors declare no conflicts of interest regarding the publication of this paper.

\section{References}

[1] Leem, J.H., Kim, S.T. and Kim, H.C. (2015) Public-Health Impact of Outdoor Air Pollution for 2(nd) Air Pollution Management Policy in Seoul Metropolitan Area, Korea. Annals of Occupational and Environmental Medicine, 27, 7. https://doi.org/10.1186/s40557-015-0058-Z

[2] Leung, A.W.Y., Chan, R.S.M., Sea, M.M.M. and Woo, J. (2017) An Overview of Factors Associated with Adherence to Lifestyle Modification Programs for Weight Management in Adults. International Journal of Environmental Research and Public Health, 14, E922. https://doi.org/10.3390/ijerph14080922

[3] WHO (2016) An Estimated 12.6 Million Deaths Each Year Are Attributable to Unhealthy Environments. Geneva.

http://www.who.int/mediacentre/news/releases/2016/deaths-attributable-to-unhealt hy-environments/en

[4] Lee, H., Myung, W., Kim, D.K., Kim, S.E., Kim, C.T. and Kim, H. (2017) Short-Term Air Pollution Exposure Aggravates Parkinson's Disease in a Population-Based Cohort. Scientific Reports, 7, Article No. 44741.

https://doi.org/10.1038/srep44741

[5] Nhung, N.T.T., Amini, H., Schindler, C., Kutlar Joss, M., Dien, T.M., Probst-Hensch, N., et al. (2017) Short-Term Association between Ambient Air Pollution and 
Pneumonia in Children: A Systematic Review and Meta-Analysis of Time-Series and Case-Crossover Studies. Environmental Pollution, 230, 1000-1008. https://doi.org/10.1016/j.envpol.2017.07.063

[6] Schultz, E.S., Litonjua, A.A. and Melén, E. (2017) Effects of Long-Term Exposure to Traffic-Related Air Pollution on Lung Function in Children. Current Allergy and Asthma Reports, 17, 41. https://doi.org/10.1007/s11882-017-0709-y

[7] Kim, H., Kim, J., Kim, S., Kang, S.H., Kim, H.J., Heo, J., et al. (2017) Cardiovascular Effects of Long-Term Exposure to Air Pollution: A Population-Based Study with 900845 Person-Years of Follow-Up. Journal of the American Heart Association, 6, e007170. https://doi.org/10.1161/JAHA.117.007170

[8] Huang, H.B., Lai, C.H., Chen, G.W., Lin, Y.Y., Jaakkola, J.J., Liou, S.H., et al. (2012) Traffic-Related Air Pollution and DNA Damage: A Longitudinal Study in Taiwanese Traffic Conductors. PLoS ONE, 7, e37412. https://doi.org/10.1371/journal.pone.0037412

[9] Carlsten, C. and Rider, C.F. (2017) Traffic-Related Air Pollution and Allergic Disease: An Update in the Context of Global Urbanization. Current Opinion in Allergy and Clinical Immunology, 17, 85-89. https://doi.org/10.1097/ACI.0000000000000351

[10] Costa, L.G., Cole, T.B., Coburn, J., Chang, Y.C., Dao, K. and Roqué, P.J. (2017) Neurotoxicity of Traffic-Related Air Pollution. Neurotoxicology, 59, 133-139. https://doi.org/10.1016/j.neuro.2015.11.008

[11] Shima, M. (2017) Health Effects of Air Pollution: A Historical Review and Present Status. Nippon Eiseigaku Zasshi, 72, 159-165. https://doi.org/10.1265/jjh.72.159

[12] Chen, S.Y., Chu, D.C., Lee, J.H., Yang, Y.R. and Chan, C.C. (2018) Traffic-Related Air Pollution Associated with Chronic Kidney Disease among Elderly Residents in Taipei City. Environmental Pollution, 234, 838-845. https://doi.org/10.1016/j.envpol.2017.11.084

[13] An, R., Zhang, S., Ji, M. and Guan, C. (2017) Impact of Ambient Air Pollution on Physical Activity among Adults: A Systematic Review and Meta-Analysis. Perspectives in Public Health, 138, 111-121. https://doi.org/10.1177/1757913917726567

[14] An, R. and Xiang, X. (2015) Ambient Fine Particulate Matter Air Pollution and Leisure-Time Physical Inactivity among US Adults. Public Health, 129, 1637-1644. https://doi.org/10.1016/j.puhe.2015.07.017

[15] Atkinson, R.W., Anderson, H.R., Sunyer, J., Ayres, J., Baccini, M., Vonk, J.M., et al. (2001) Acute Effects of Particulate Air Pollution on Respiratory Admissions: Results from APHEA 2 Project. Air Pollution and Health: A European Approach. The American Journal of Respiratory and Critical Care Medicine, 164, 1860-1866. https://doi.org/10.1164/ajrccm.164.10.2010138

[16] Gent, J.F., Triche, E.W., Holford, T.R., Belanger, K., Bracken, M.B., Beckett, W.S., et al. (2003) Association of Low-Level Ozone and Fine Particles with Respiratory Symptoms in Children with Asthma. JAMA, 290, 1859-1867. https://doi.org/10.1001/jama.290.14.1859

[17] Campbell, M.E., Li, Q., Gingrich, S.E., Macfarlane, R.G. and Cheng, S. (2005) Should People Be Physically Active Outdoors on Smog Alert Days? Canadian Journal of Public Health, 96, 24-28. https://doi.org/10.1007/BF03404009

[18] Nel, A. (2005) Atmosphere. Air Pollution-Related Illness: Effects of Particles. Science, 308, 804-806. https://doi.org/10.1126/science.1108752

[19] Sharman, J.E. (2005) Clinicians Prescribing Exercise: Is Air Pollution a Hazard? Medical Journal of Australia, 182, 606-607. 
https://doi.org/10.5694/j.1326-5377.2005.tb06843.x

[20] de Nazelle, A., Rodríguez, D.A. and Crawford-Brown, D. (2009) The Built Environment and Health: Impacts of Pedestrian-Friendly Designs on Air Pollution Exposure. Science of the Total Environment, 407, 2525-2535.

https://doi.org/10.1016/j.scitotenv.2009.01.006

[21] Nowak, D., Crane, D. and Stevens, J. (2006) Air Pollution Removal by Urban Trees and Shurbs in the United States. Urban Forestry \& Urban Greening, 4, 115-123. https://doi.org/10.1016/j.ufug.2006.01.007

[22] Tzoulas, K., Korpela, K., Venn, S., YliPelkonen, V., Kazmierczak, A., Niemela, J., et al. (2007) Promoting Ecosystem and Human Health in Urban Areas Using Green Infrastructure: A Literature Review. Landscape and Urban Planning, 81, 167-178. https://doi.org/10.1016/j.landurbplan.2007.02.001

[23] Jansson, M. (2014) Green Space in Compact Cities: The Benefits and Values of Urban Ecosystem Services in Planning. The Nordic Journal of Architectural Research, 26, 139-160.

[24] Liu, H.L. and Shen, Y.S. (2014) The Impact of Green Space Changes on Air Pollution and Microclimates: A Case Study of the Taipei Metropolitan Area Sustain. Sustainability, 6, 8827-8855. https://doi.org/10.3390/su6128827

[25] Nowak, D.J. and Heisler, G.M. (2010) Air Quality Effects of Urban Trees and Parks. National Recreation and Park Association, Ashburn.

[26] Gromke, C. and Blocken, B. (2015) Influence of Avenue-Trees on Air Quality at the Urban Neighborhood Scale. Part II: Traffic Pollutant Concentrations at Pedestrian Level. Environmental Pollution, 196, 176-184. https://doi.org/10.1016/j.envpol.2014.10.015

[27] Wania, A., Bruse, M., Blond, N. and Weber, C. (2011) Analysing the Influence of Different Street Vegetation on Traffic-Induced Particle Dispersion Using Microscale Simulations. Journal of Environmental Management, 94, 91-101. https://doi.org/10.1016/j.jenvman.2011.06.036

[28] Lodge, J.P.A. (1988) Methods of Air Sampling and Analysis. Lewis Publisher Inc., Chelsea.

[29] Scheeren, B.A. and Adema, E.H. (1996) Monitoring Ambient Ozone with a Passive Measurement Technique Method, Field Results and Strategy. Water, Air \& Soil Pollution, 91, 335-350. https://doi.org/10.1007/BF00666268

[30] Custódio, D., Cerqueira, M., Alves, C., Nunes, T., Pio, C., Esteves, V., et al. (2016) A One-Year Record of Carbonaceous Components and Major Ions in Aerosols from an Urban Kerbside Location in Oporto, Portugal. Science of the Total Environment, 562, 822-833. https://doi.org/10.1016/j.scitotenv.2016.04.012

[31] Hama, S.M.L., Cordell, R.L. and Monks, P.S. (2017) Quantifying Primary and Secondary Source Contributions to Ultrafine Particles in the UK Urban Background. Atmospheric Environment, 166, 62-78. https://doi.org/10.1016/j.atmosenv.2017.07.013

[32] Wang, Q.J., Nan, Y.S., Li, X., Yu, F., Guo, Y. and Zhang, R. (2017) Carbonaceous Species in PM2.5 and PM10 in Urban Area of Zhengzhou in China: Seasonal Variations and Source Apportionment. Atmospheric Research, 191, 1-11. https://doi.org/10.1016/j.atmosres.2017.02.003

[33] Cichowicz, R., Wielgosiński, G. and Fetter, W. (2017) Dispersion of Atmospheric Air Pollution in Summer and Winter Season. Environmental Monitoring and Assessment, 189, 605. https://doi.org/10.1007/s10661-017-6319-2 
[34] Trinh, T.T., Le, T.T., Nguyen, T.D.H. and Tu, B.M. (2018) Temperature Inversion and Air Pollution Relationship, and Its Effects on Human Health in Hanoi City, Vietnam. Environmental Geochemistry and Health, 41, 929-937. https://doi.org/10.1007/s10653-018-0190-0

[35] McDonald, R., Kroeger, T., Boucher, T., Longzhu, W. and Salem, R. (2016) Planting Healthy Air: A Global Analysis of the Role of Urban Trees in Addressing Particulate Matter Pollution and Extreme Heat. The Nature Conservancy, Arlington County, 136.

[36] Nowak, D.J., Hirabayashi, S., Bodine, A. and Greenfield, E. (2014) Tree and Forest Effects on Air Quality and Human Health in the United States. Environmental Pollution, 193, 119-129. https://doi.org/10.1016/j.envpol.2014.05.028

[37] Llop, E., Pinho, P., Ribeiro, M.C., Pereira, M.J. and Branquinho, C. (2017) Traffic Represents the Main Source of Pollution in Small Mediterranean Urban Areas as Seen by Lichen Functional Groups. Environmental Science and Pollution Research, 24, 12016-12025. https://doi.org/10.1007/s11356-017-8598-0

[38] Fleck, A.S., Vieira, M., Amantéa, S.L. and Rhoden, C.R. (2014) A Comparison of the Human Buccal Cell Assay and the Pollen Abortion Assay in Assessing Genotoxicity in an Urban-Rural Gradient. International Journal of Environmental Research and Public Health, 11, 8825-8838. https://doi.org/10.3390/ijerph110908825

[39] Pasquier, A. and Andre, M. (2016) Considering Criteria Related to Spatial Variabilities for the Assessment of Air Pollution from Traffic. 14th World Conference on Transport Research, Shanghai, 10-15 July 2016, Article ID: 01453177.

[40] Chang, S.Y., Vizuete, W., Valencia, A., Naess, B., Isakov, V., Palma, T., et al. (2015) A Modeling Framework for Characterizing Near-Road Air Pollutant Concentration at Community Scales. Science of the Total Environment, 538, 905-921. https://doi.org/10.1016/j.scitotenv.2015.06.139

[41] Zhang, K. and Batterman, S. (2013) Air Pollution and Health Risks Due to Vehicle Traffic. Science of the Total Environment, 450-451, 307-316.

https://doi.org/10.1016/j.scitotenv.2013.01.074 